\title{
Microteaching: An Introspective Case Study with Middle School Teachers in New York City Public Schools
}

\author{
Lauren B. Birney ${ }^{1, *}$, Joyce Kong ${ }^{1}$, Brian R. Evans ${ }^{1}$, Macey Danker ${ }^{1}$ \& Kathleen Grieser ${ }^{1}$ \\ ${ }^{1}$ School of Education, Pace University, 163 William Street, 11 th Floor, New York, NY 10038, USA \\ *Correspondence: School of Education, Pace University, 163 William Street, 11th Floor, New York, NY 10038, USA. \\ Tel: 1-212-346-1512 E-mail: lbirney@pace.edu
}

Received: June 6, 2017

Accepted: July 4, 2017 Online Published: August 20, 2017

doi:10.5430/jct.v6n2p1

URL: https://doi.org/10.5430/jct.v6n2p1

\begin{abstract}
The purpose of this study was to investigate the potential impacts of microteaching on experienced teachers participating in the Community Enterprise for Restoration Science (CCERS) Teaching Fellowship at Pace University as part of a National Science Foundation-funded research project on the education model known as the Curriculum and Community Enterprise for Restoration Science (CCERS). The program builds a learning community of teachers in the fellowship program as they participated in monthly workshops in cohorts and continuously interact with each other during the two years of the program. Each teacher in Cohort 1 of the CCERS Fellowship was required to provide a brief lesson that they have used in the classrooms from the CCERS curriculum. Generally, the Teaching Fellows' micro-lessons contained appropriate objectives presented to the class aligned well to the objectives of the CCERS initiative, which focused on harbor restoration learning within a STEM context. By conducting field studies at restoration stations that students set up near their schools, students across all schools learned about the biology, chemistry, ecology and history of the Hudson River. In addition to teaching science content, all teachers incorporated lessons on helping students to develop literacy strategies to build vocabulary. The microteaching modules allowed for teachers to gain insight as to how the curriculum was being implemented into other teachers' classrooms. It permitted for teachers' exposure to the various teaching methods and resources being used to assist underrepresented students and students where English is a second language.
\end{abstract}

Keywords: microteaching; in-service; middle school; STEM; Billion Oyster Project (BOP); Curriculum and Community Enterprise for Restoration Science (CCERS); restoration science

\section{Introduction}

The purpose of this research is to investigate the potential impacts of microteaching on experienced teachers participating in the Community Enterprise for Restoration Science (CCERS) Teaching Fellowship at Pace University as part of a National Science Foundation-funded research project on the education model known as the Curriculum and Community Enterprise for Restoration Science (CCERS) (DRL 1440869/PI Birney).

The CCERS model is composed of five pillars: (1) Teacher Training Curriculum; (2) Student Learning Curriculum; (3) Digital Platform; (4) Afterschool and Summer Mentoring; and (5) Community Restoration- Based Exhibits. As a central pillar, the CCERS Fellowship aims to improve STEM education in public schools by linking teaching and learning to ecosystem restoration and engaging students in hands-on environmental field science during their regular school day. The project also strongly emphasizes the use of computer science and digital tools for environmental monitoring, citizen science, stewardship, and advocacy. Through participation the fellowship, CCERS Teaching Fellows play a key role in advancing the CCERS model and answering the project's core research questions.

The theoretical framework for this study is grounded in Vygotsky's (1987) sociocultural theory in which learning is a social process that happens collaboratively within communities of learners. The teacher guides learning, which is accomplished through a process of "enculturation into a community of practice (Cobb, 1994, p. 13). The individual and collective group learning processes are directly related (Cobb \& Yackel, 1996). Microteaching, and the teacher classroom interactions that are part of the process, are directly grounded in learning primarily through social classroom 
interactions.

While many studies have examined the effects of microteaching in pre-service teacher education curricula, little research exists on how microteaching activities in-service teacher training programs may impact teaching and learning outcomes. Allen (1966) suggested that microteaching can also be beneficial to experienced personnel as evidenced by changes in teacher perceptions of their own teaching behaviors upon re-teaching a microteaching lesson.

Findings from research performed on pre-service teacher education programs indicate the potential added value of continuing with microteaching practices in ongoing professional development for veteran teachers. For example, Mensah (2011) studied three elementary pre-service teacher experiences in co-planning and co-teaching in a fourth to fifth grade science classroom in New York City and found that the microteaching experience increased teacher self-efficacy to teach science. Microteaching offered a collaborative context to learn and enacted principles of culturally relevant teaching in an authentic classroom setting with students of diverse backgrounds, learning styles, and interest. According to Mensah, the microteaching experience enabled the pre-service teachers to feel success in teaching science so that their students also experienced success in learning science. Because of the microteaching experience, one pre-service teacher in the study was able to appreciate the importance of visual aids to enhance student learning. Another student was calmer on her second lesson after she had the opportunity to observe her microteaching from day one.

A study by Remesh (2013) found that microteaching may also help to reduce anxiety levels and enhance skills in problem solving, critical thinking, questioning, and reflective thinking for students. Remesh focused on the medical curricula in India, and argued that microteaching was an effective technique for learning effective teaching. The study findings were that the use of microteaching in the science context was a proven method to obtain improvement in the instructional experience. According to Remesh, utilization of expanded microteaching activities in medicine, mathematics, and science teaching practical courses significantly reduced students' level of anxiety. The author suggested that in the medical teaching framework, microteaching allowed students to learn each skill to the maximum extent as there was a chance of listening, observing, and practicing. Remesh found that microteaching helped novice teachers develop skills and assisted them in comparing the effectiveness a variation in their lessons. Microteaching could enhance the skills of problem solving, critical thinking, questioning, and reflective thinking. It was found to be beneficial because it enabled students to transform difficult topics into learnable topics.

Similarly, Arsal (2015) designed a study to investigate how microteaching impacts pre-service teachers' critical thinking dispositions. According to Arsal, pre-service teachers should be improving upon their questioning, critical thinking skills, and dispositions in their methods courses by participating in a democratic classroom, teacher activities, and student centered teaching methods (Arsal, 2015, p. 141). Conducted at a public university in northern Turkey, 70 pre-service teachers in a Turkish language teacher education program participated in this study. The results indicated that the critical thinking dispositions of both the experimental group and control group increased; however, the experimental group showed a statistically significant increase in progress with critical thinking skills compared to the control group. Arsal concluded "inquiry-based experience is effective in increasing the critical thinking dispositions of pre-service teachers" (p. 148).

Musa (2014) said, "[i]t is very important for the quality of the educations that teachers have experience with their own presentations in front of their friends and improve their teaching skills before starting to work as a teacher" (p. 1319). Musa (2014) interviewed primary pre-service teachers of public schools in Turkey. The study evaluated the use of the microteaching methods by collecting the opinions of 24 primary pre-service teacher candidates by surveying them with a semi-structured interview form. This form consisted of two parts, which asked questions about personal information and research questions. Musa (2014) found that including microteaching in pre-service teaching courses increased competency in teaching skills. Furthermore, incorporating video recordings into microteaching gives participants an opportunity to self-evaluate their strengths and weaknesses, as well as evaluate their peers.

Baştürk (2016) examined the effectiveness of microteaching techniques in mathematics of primary pre-service teachers using a quantitative approach. Baştürk focused on elementary level pre-service teachers' pedagogical knowledge of fractions, obtained by a microteaching evaluation form. The study was also conducted at a public university in northern Turkey with 131 participating third grade pre-service teachers. The participants were assessed using "a five-point Likert-type microteaching evaluation form (MEF)" which included 32 criterion ranging from "very poor= 1" to "very good= 5" (Baştürk, 2016, p. 241). The results indicated that the pre-service teachers needed improvement in various criterions, such as assessment, group teaching, and incorporating students' interests into teaching. The criterion "preparation to teaching and use of materials" had the highest average score.

In another study, Baştürk and Taştepe (2015) again examined elementary level pre-service teachers and the difficulties 
they had while teaching mathematics with the microteaching method. Fifteen third grade pre-service teachers were given a descriptive study assessed in three stages: self-assessment, peer-assessment, and expert assessment. Their task was to prepare five lesson objectives related to a mathematics concept provided in the curriculum. Participants struggled with classroom management, organization of group studies, overcoming unexpected things, and encouraging students' class participation (Baştürk \& Taştepe, 2015). The authors claimed microteaching gives pre-service teachers an opportunity to transfer their theoretical knowledge into real-world practice and bring to light their strengths and weaknesses in learning and teaching.

Finally, Luiz Adrian, Zeszotarski, and Ma (2015) studied how microteaching tasks assigned to pharmacy students in a communications course helped them with problem solving and critical thinking skills. By participating in active role-playing, student appreciation and knowledge of effective oral communication was enhanced, which translated to improve their competence in professional teamwork. In addition, the microteaching activities fostered an improvement in student written communication and public speaking skills.

\section{Methods}

\subsection{BOP-CCERS Teaching Fellowship}

As a two-year professional development program, the CCERS Teaching Fellowship prepares middle-school teachers to engage their students in hands-on environmental science and restoration ecology in and around New York Harbor. The Fellowship is open to New York City Department of Education middle school teachers working in Title I-funded schools. Pace University's School of Education, a medium-sized university in New York, hosts the fellowship classes at its lower Manhattan campus and New York Harbor Foundation runs outdoor field trainings at Billion Oyster Project headquarters on Governors Island. Classes and trainings are taught by guest experts, scientists from Columbia University's Lamont-Doherty Earth Observatory, and curriculum specialists from New York Harbor Foundation. Scientists focus primarily on providing content area support for the middle school teachers and discussing salient issues pertaining to the New York Harbor estuary.

\subsection{Research Design}

Table 1. Rubric for Microteaching for CCERS Teaching Fellowship 2015

\begin{tabular}{|c|c|c|c|}
\hline & Exemplary (2 points) & Satisfactory (1 point) & Unsatisfactory (0 points) \\
\hline $\begin{array}{l}\text { Objective(s)/ } \\
\operatorname{Aim}(\mathrm{s})\end{array}$ & $\begin{array}{l}\text { The objective(s)/aim(s) } \\
\text { is/are clearly stated. }\end{array}$ & $\begin{array}{l}\text { The objective(s)/aim(s) } \\
\text { is/are somewhat stated. }\end{array}$ & $\begin{array}{l}\text { The objective(s)/aim(s) is/are } \\
\text { not clearly stated or not stated at } \\
\text { all. }\end{array}$ \\
\hline $\begin{array}{l}\text { Classroom } \\
\text { Management and } \\
\text { Organization }\end{array}$ & $\begin{array}{l}\text { The teacher demonstrates } \\
\text { proper classroom } \\
\text { management throughout the } \\
\text { lesson. Further, the lesson } \\
\text { was well organized. }\end{array}$ & $\begin{array}{l}\text { The teacher somewhat } \\
\text { demonstrates proper classroom } \\
\text { management throughout the } \\
\text { lesson. Further, the lesson was } \\
\text { somewhat organized. }\end{array}$ & $\begin{array}{l}\text { The teacher displays poor } \\
\text { classroom management } \\
\text { throughout the lesson. Further, } \\
\text { the lesson was not organized. }\end{array}$ \\
\hline $\begin{array}{l}\text { Motivation/ Hook } \\
\text { and Engagement }\end{array}$ & $\begin{array}{l}\text { The teacher used an } \\
\text { Interesting motivation/hook } \\
\text { to get students interested in } \\
\text { the lesson. Further, the } \\
\text { teacher engaged the class } \\
\text { throughout the lesson. }\end{array}$ & $\begin{array}{l}\text { The teacher used an acceptable } \\
\text { motivation/hook to get students } \\
\text { interested in the lesson. } \\
\text { Further, the teacher somewhat } \\
\text { engaged the class throughout } \\
\text { most of the lesson. }\end{array}$ & $\begin{array}{l}\text { A very poor motivation/hook } \\
\text { was used to get students } \\
\text { interested in the lesson, } \\
\text { or none was used at all. } \\
\text { Further, the teacher did not } \\
\text { engage the class through most of } \\
\text { the lesson. }\end{array}$ \\
\hline $\begin{array}{l}\text { Science Content } \\
\text { and Standards }\end{array}$ & $\begin{array}{l}\text { The science is completely } \\
\text { correct and the lesson is } \\
\text { standards based. The } \\
\text { lesson integrates marine } \\
\text { science from BOP. }\end{array}$ & $\begin{array}{l}\text { The science is mostly correct } \\
\text { and the lesson is somewhat } \\
\text { standards based. The lesson } \\
\text { somewhat integrates marine } \\
\text { science from BOP. }\end{array}$ & $\begin{array}{l}\text { The science is often incorrect } \\
\text { and/or the lesson is not } \\
\text { standards based. The lesson } \\
\text { does not integrate marine } \\
\text { science from BOP. }\end{array}$ \\
\hline Assessment & $\begin{array}{l}\text { An assessment is used } \\
\text { that is used to determine } \\
\text { to what degree the } \\
\text { objective(s) has/have } \\
\text { been met. }\end{array}$ & $\begin{array}{l}\text { An assessment is used that } \\
\text { somewhat determines to what } \\
\text { degree the objective(s) } \\
\text { has/have been met. }\end{array}$ & $\begin{array}{l}\text { Either no assessment is } \\
\text { given, or the assessment } \\
\text { is of poor quality to } \\
\text { determine if the objective(s) } \\
\text { has/have been met. }\end{array}$ \\
\hline
\end{tabular}


The program builds a learning community of teachers in the fellowship program as they participated in monthly workshops in cohorts and continuously interact with each other during the two years of the program. Each teacher in Cohort 1 of the CCERS Fellowship was required to provide a brief lesson that they have used in the classrooms from the CCERS curriculum. Cohort 2 teachers participated as the "students" during the microteaching lessons. Teachers were instructed to teach innovative, interesting lessons that take into current practices in STEM education and lasting no longer than 15 minutes. Each micro-lesson concluded with 5 minutes of feedback from the class and the facilitators. Additionally, presenters were asked not to give any background or explanatory presentation before the lesson, and to simply start the lesson as they normally would with a class of students.

The rubric below was used as an assessment tool for our practice. Cohort 1 fellows included 17 middle school teachers across 10 schools. There are 24 teachers from 14 middle schools in Cohort 2. Two Cohort 1 Teaching Fellows each led a microteaching session at each monthly meeting across the 12 months of 2015.

\section{Results}

Generally, the Teaching Fellows' micro-lessons contained appropriate objectives presented to the class aligned well to the objectives of the CCERS initiative, which focused on harbor restoration learning within a STEM context. The lessons ranged from somewhat engaging to highly engaging for the class. However, in some instances the Teaching Fellows conducted the class as if Cohort 2 were their actual students while other Teaching Fellows conducted their lessons talking to Cohort 2 as experienced teachers rather than as their "students." This practice was highly discouraged by the researchers in this study. However, this practice persisted from time to time for the remainder of the project. Two of the study authors regularly conduct microteaching within their own science and mathematics teacher preparation courses and found that the pre-service teachers, and even early career in-service teachers, conducted their lessons with their classmates as "students." The authors hypothesize this may be due to the difference between samples. Pre-service teachers may not view their classmates as colleagues in the same manner in which experienced in-service teachers do. This should be further investigated in subsequent studies.

By conducting field studies at restoration stations that students set up near their schools, students across all schools learned about the biology, chemistry, ecology and history of the Hudson River. Students conducted online research on harbor organisms, practiced data documentation, analysis, and representing it with proportions and linear equations. Additional learning evidence comprised of student-created stop-motion videos and student-generated handbook of harbor inhabitants.

Several Cohort 1 teachers set up an oyster tank in their classrooms following their field studies at their restoration station. One teacher shared his experience of setting up a tank through his microteaching lesson. He told the class that it was like having a class pet and the tank allowed students to have a stake in oyster survival. In addition to identifying the species in the tank, students were able to monitor predator and prey relationships and practiced water quality testing on a daily basis.

In addition to teaching science content, all teachers incorporated lessons on helping students to develop literacy strategies to build vocabulary. Lessons included the use of word wall activities, games with vocabulary cards, and word drawings to support reading and writing performance tasks. Finally, another teacher made connections to local regional geology in her lessons and had students build 3D models to make predictions on what happens to pesticides and runoff in a watershed.

\section{Discussion}

The microteaching modules allowed for teachers to gain insight as to how the curriculum was being implemented into other teachers' classrooms. It permitted for teacher's exposure to the various teaching methods and resources being used to assist underrepresented students and students where English is a second language. Teachers shared their various support structures, methods for scaffolding of content and implementation of both the field science components as well as the in class curriculum. The modules seemed useful in providing a lens and exposure for both the existing cohort and the new cohort just commencing the program. Cohort 1 teachers also received valuable feedback from Cohort 2 teachers, harbor research scientists, and curriculum specialists on additional methods of scaffolding, ideas for extension activities, and interdisciplinary connections.

Further research should investigate the effect of microteaching for both the presenters and the "students" in actual classrooms. The authors expect that both the presenters and "students" will benefit in their teaching by conducting and observing simulated teaching with lessons from the harbor restoration science curriculum. The authors also anticipate 
continuing this research and expect to receive more evidence on the impacts of microteaching for Cohort 2 Fellows in their mentoring reports submitted with Cohort 3 Fellows.

Themes found in the literature review were increasing teacher self-efficacy (Mensah, 2011), reducing anxiety and enhancing skills like problem solving (Remesh, 2013), improving critical thinking and dispositions (Arsal, 2015), and increasing teacher competency (Musa, 2014). It was found that allowing the teachers to have opportunities to demonstrate to their colleagues the manner in which they integrated the concepts from the program (e.g., ecosystem restoration, environmental field science, etc.), the teachers had opportunities to test their ideas and receive feedback from colleagues and the faculty/scientists in the program. This serves to increase the teachers' confidence in their ability to integrate the program concepts into their own teaching. Future studies should follow the teachers back into their schools to determine how effectively they integrated program goals into their teaching and to survey teachers to determine increased confidence, self-efficacy, dispositions, and reduction in anxiety.

\section{References}

Allen, D. W. (1966). Micro-teaching: A new framework for in-service education. The High School Journal, 49(8), 355-362.

Arsal, Z. (2015). The effects of microteaching on the critical thinking dispositions of pre-service teachers. AJTE Australian Journal of Teacher Education, 40(3), 140-153. https://doi.org/10.14221/ajte.2014v40n3.9

Cobb, P. (1994). Where is the mind? Constructivist and sociocultural perspectives on mathematical development. Educational Researcher, 23(7), 13-20. https://doi.org/10.3102/0013189X023007013

Cobb, P., \& Yackel, E. (1996). Constructivist, emergent, and sociocultural perspectives in the context of

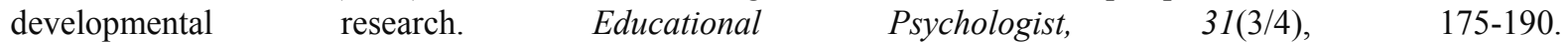
https://doi.org/10.1080/00461520.1996.9653265

Cooper, J. M., \& Allen, D. W. (1970). Microteaching: History and present status. ERIC Clearinghouse on Teacher Education. Retrieved from http://files.eric.ed.gov/fulltext/ED036471.pdf

Luiz Adrian J. A., Zeszotarski, P., \& Ma, C. (2015). Developing pharmacy student communication skills through role-playing and active learning. American Journal of Pharmaceutical Education, 79(3), 44. https://doi.org/10.5688/ajpe79344

Mensah, F. M. (2011). A case for culturally relevant teaching in science education and lessons learned for teacher education. The Journal of Negro Education, 80(3), 296-309,437.

Remesh, A. (2013). Microteaching, an efficient technique for learning effective teaching. Journal of Research in Medical Sciences, 18(2), 158-163.

Vygotsky, L. S. (1987). Thinking and speech. In R. W. Rieber \& A. S. Carton (Eds.), The collected works of Vygotsky, L. S. (Vol. 1): Problems of general psychology, 39-285. New York, NY: Plenum. 